\title{
GAMBARAN HISTOPATOLOGI PARU PADA MENCIT (Mus musculus) YANG DIPAPAR ASAP ROKOK KRETEK AKIBAT PENGARUH PEMBERIAN INFUSA TEH HIJAU (Camellia sinensis)
}

\author{
Rondius Solfaine ${ }^{1}$, Olan Rahayu Puji Astuti Mussa ${ }^{1}$, Apriska Ayuningtias ${ }^{1}$, Dyah Widhowati ${ }^{1 *}$ \\ ${ }^{1}$ Fakultas Kedokteran Hewan, Universitas Wijaya Kusuma Surabaya \\ *Email : dyahwidho@gmail.com
}

\begin{abstract}
This study was conducted to determine the effect of antioxidant administration from green tea infusion (Camellia sinensis) on damage to the histological structure of the lung exposed to clove cigarette smoke in mice (Mus muscullus). Free radicals in cigarette smoke such as tar, nicotine, and carbon monoxide can cause various damages to the lung organs due to oxidative stress caused by the reaction of ultrafine particles with cells. A total of 27 mice were taken from the Biochemical Laboratory of Airlangga University, Surabaya. In this study mice (Mus muscullus) were exposed to kretek cigarette smoke in the smoking chamber for 15 minutes in a period of 2 weeks, used 2 variants of antioxidant doses of green tea infusion of 0.45 $\mathrm{gr}$ to $0.6 \mathrm{gr}$. After the treatment was completed, the preparation of the mice's pulmonary organ preparations and damage to the structure of the lung organ were observed in 9 visual fields. The results showed that there was a relationship between the amount of cigarette smoke exposed and damage to the lung organs of mice when given antioxidant green tea. The administration of green tea antioxidants reduced inflammation of the lung organ infiltration of inflammatory cells by $44 \%$, edema by $55 \%$, and destruction of septa alveoli by $88 \%$.
\end{abstract}

Keywords: Green tea (Camellia sinensis), mice (Mus muscullus), cell infiltration, edema, destruction

\section{PENDAHULUAN}

Merokok sebenarnya tidak memberikan efek yang baik bagi tubuh, namun karena kandungan rokok yang bersifat adiktif sehingga banyak orang yang susah berhenti merokok. Efek buruk yang terlihat secara langsung dari asap rokok menyebabkan batuk maupun sesak ketika terhirup asam rokok. Terdapat 7.000 bahan kimia ditembakau, dan lebih dari 250 racun itu menjadi karsinogenik.Polisiklik Aromatik Hidrokarbon (PAH), kadmium dan berilium (logam beracun), hidrogen sianida, karbon monoksida, dan amonia (Batubara dkk, 2013).

Asap termasuk radikal bebas yang sering terpapar pada tubuh kita, dan sampai saat ini tidak ditemukan cara efektif untuk mencegah maupun memperbaiki kerusakan akibat paparan asap rokok. Radikal bebas masuk dan merusak sel jaringan dalam tubuh, terutama merusak organ tubuh seperti paru. Proses pembentukan radikal bebas dalam tubuh berasal dari reduksi oksidasi biokimiawi yang melibatkan oksigen dan merupakan bagian dari proses metabolisme sel normal.

Teh hijau (Camelia sinensis) adalah jenis tanaman herbal dari Cina. Tanaman ini merupakan tanaman yang dibudidayakan di Asia Tenggara sebagai bahan baku obat tradisional. Kadungan polifenol dalam jumlah yang tinggi dapat memperbaiki fungsi organ dan sistem pertahanan tubuh, seperti flavonol, flavones, flavonem isoflavon, antosianin dan katekin.Sebagai bahan bioaktif, antosianin dan katekin berfungsi menangkap radikal bebas sehingga dapat menghambat terjadinya kerusakan pada membran sel. (Zhao, et al., 2019).

\section{MATERI DAN METODE}

Penelitian ini dilakukan di Laboratorium Biokimia Fakultas Kedokteran Universitas Airlangga Surabaya dan pembuatan preparat histopatologi akan dilakukan di Fakultas Kedokteran Universitas Airlangga Surabaya. Penelitian 
dilaksanakan pada 29 Mei sampai 12 Juni 2020.

Penelitian ini bersifat eksperimental laboratorium murni dengan memberikan perlakuan terhadap sampel kemudian diobservasi dan dilakukan pengambilan data. Penelitian ini dilakukan tanpa pengulangan data dengan P0 sebagai kelompok kontrol, P1 sebagai kelompok perlakuan dimana mencit diberikan infusa the hijau peroral dengan dosis 1 dan dipapar asap rokok, dan P2 sebagai kelompok dimana mencit diberikan infusa the hijau secara peroral dengan dosis 2 dan dipapar asap rokok. Sampel mencit terdiri dari 27 ekor mencit, yang diperoleh dari Laboraturium Biokimia Universitas Airlangga Surabaya dibagi menjadi 3 kelompok, masing-masing kelompok terdiri dari 9 ekor mencit. Dilakukan sortir jenis kelamin jantan dan penimbangan mencit untuk penentuan dosis dan perlakuan.

Pada percobaan ini pemberian seduhan teh hijau pada mencit dihitung dengan menggunakan tabel konversi tikus ke mencit. Nilai konversi dari tikus ke mencit adalah 0,14 , sehingga diperoleh dosis seduhan daun teh hijau untuk mencit, yaitu $0,108 \times 0,14=0,015 \mathrm{gr} / \mathrm{bb} / \mathrm{hari}$ (Anindita, 2012).

Dilakukan percobaan dengan P0 sebagai kontrol, kelompok ini hanya diberikan makan dan minum secara ad libitum. Kelompok P1 sebagai perlakuan diberikan infusa teh hijau dengan dosis $1 \quad(0,015$ gr/bb/hari) secara peroral menggunakan spuit 1cc, kemudian dilakukan pemaparan asap rokok sebanyak satu batang selama 14 hari. Kelompok P2 sebagai perlakuan diberikan infusa teh hijau dengan dosis 2 $(0,020$ gr/bb/hari $)$ secara peroral menggunakan spuit 1cc, kemudian dilakukan pemaparan asap rokok sebanyak 1 batang dalam sehari selama 14 hari. Kemudian dilakukan euthanasi hari ke 15 dan dibuat preparat histopat.

Analisis data dilakukan dengan menggunakan data semi kuantitatif metode skoring, untuk membedakan perlakuan dengan kontrol dilakukan analisis statistik Kruskal-Wallis dan dilanjutkan dengan analisis Mann Whitney untuk membedakan perbedaan antar kelompok, dengan tingkat kepercayaan signifikasi.

\section{HASIL}

Tabel 1. Rata-rata Skoring Histopatologi dari data Kruskal Wallis dan Mann Whitney

\begin{tabular}{ccc}
\hline & Perlakuan & $\begin{array}{c}\text { Rata-rata skor } \pm \\
\text { SD }\end{array}$ \\
\hline $\begin{array}{c}\text { Sel } \\
\text { radang }\end{array}$ & P0 & $0,0^{\mathrm{a}} \pm 0,0$ \\
\hline & P1 & $3,0^{\mathrm{b}} \pm 0,0$ \\
\hline & P2 & $2,4^{\mathrm{c}} \pm 0,7$ \\
\hline & P0 & $0,0^{\mathrm{a}} \pm 0,0$ \\
\hline Edema & P1 & $2,1^{\mathrm{b}} \pm 0,3$ \\
\hline & P2 & $1,3^{\mathrm{b}} \pm 1,0$ \\
\hline Destruksi & P0 & $0,0^{\mathrm{a}} \pm 0,0$ \\
\hline & $\mathrm{P} 1$ & $1,3^{\mathrm{b}} \pm 1,0$ \\
\hline & $\mathrm{P} 2$ & $0,6^{\mathrm{b}} \pm 0,9$ \\
\hline
\end{tabular}

Keterangan : Huruf beda di belakang nilai rata-rata menunjukkan perbedaan yang sangat nyata $(\mathrm{P}<0,01)$.

Hasil superscrip dari infiltrasi sel radang dan edema menujukkan perbedaan yang sangat nyata antara nilai mean dan skor defiasi dengan nilai $\mathrm{p}<0,01$. Sedangkan untuk hasil superscrip dari destruksi menujukkan perbedaan yang tidak berbeda nyata antara nilai mean dan skor defiasi dengan nilai $p<0,05$. Nilai $p$ adalah derajat probabilitas. Berikut adalah gambaran mikroskopis paru dengan pemberian infusa teh hijau yang dipapar asap rokok

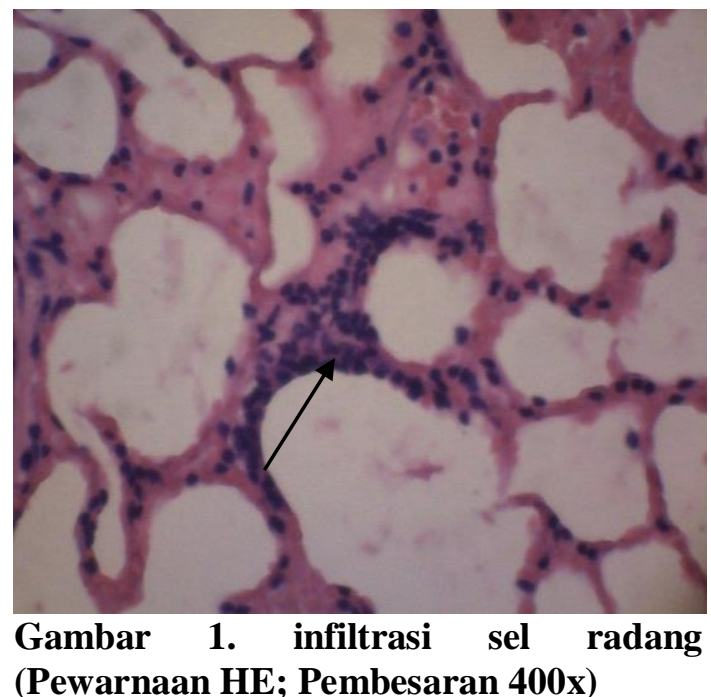




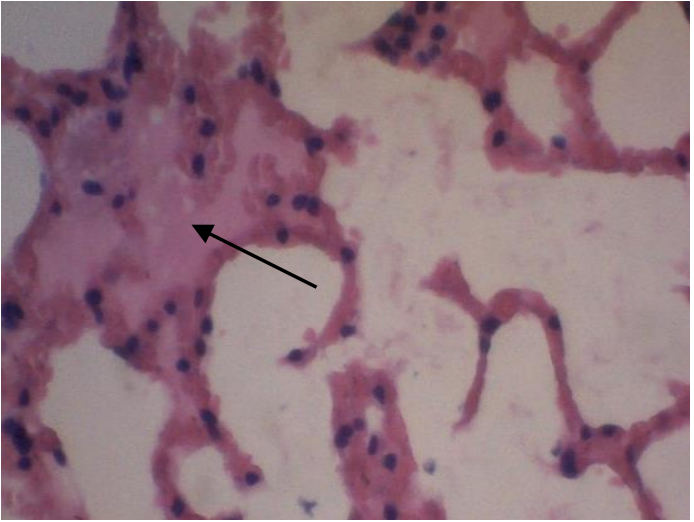

Gambar 2. edema (Pewarnaan HE; Pembesaran 400x)

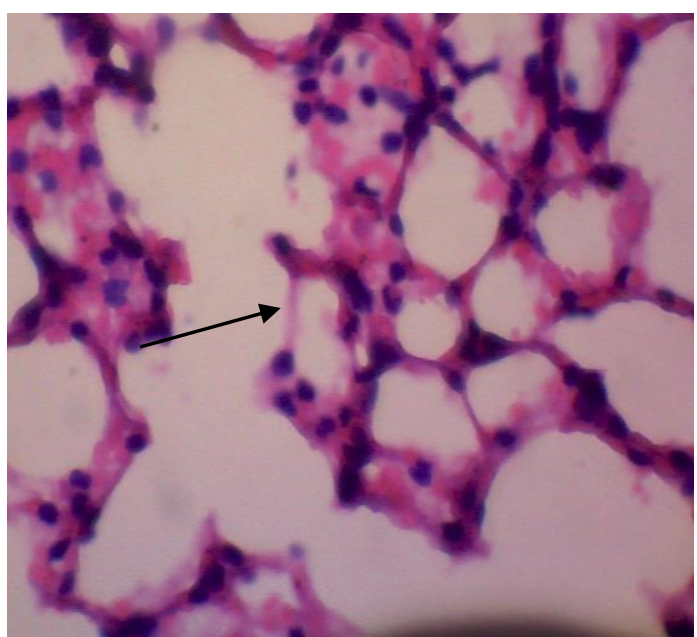

Gambar 3. Destruksi septa alveolus (Pewarnaan HE; Pembesaran 400x)

\section{PEMBAHASAN}

Berdasarkan data skoring yang diperoleh menunjukkan kerusakan struktur histologis paru mencit berupa infiltrasi sel radang mengalami penurunan $44 \%$, edema mengalami penurunan $55 \%$, dan destruksi septa alveolus mengalami penurunan $88 \%$. Hal ini menunjukkan bahwa zat yang terkandung pada teh hijau mampu memberikan efek proteksi terhadap struktur histologis paru mencit yang dipapar asap rokok.Data yang diperoleh dari penelitian yang telah dihitung dengan uji Kruskal Wallis dan Mann Whitney membuktikan adanya pengaruh pemberian teh hijau terhadap struktur histologis paru yang dipapar asap rokok kretek pada mencit. Pada penelitian ini kerusakan histologis paru mencit dinilai berdasarkan adanya infiltrasi sel radang, edema dan destruksi septum alveolus. Dari hasil uji statistik, menunjukkan perbedaan yang bermakna antara kelompok kontrol dan kelompok perlakuan 1, kelompok perlakuan 1 dengan kelompok perlakuan 2.

Oksidan yang terkandung pada asap rokok menyebabkan kerusakan oksidatif yang signifikan yang disebabkan oleh ketidakseimbangan antara protease dan anti protease. Proteolisis dan kerusakan oksidatif dapat menimbulkan kerusakan dinding alveolus yang lama-kelamaan merusak seluruh organ paru. Menurut Ravindranath, N.H., dan Ravindranath, M.H (2011) mengungkapkan bahwa EGCG merupakan polifenol yang paling banyak dalam teh hijau dan memiliki aktivitas anti inflamasi serta anti proliferasi yang poten, selektif dalam menghambat pertumbuhan sel dan menginduksi terjadinya apoptosis pada sel kanker tanpa menganggu sel yang normal. EGCG mampu menekan aktivasi NFkappaB sehingga dapat menekan terjadinya inflamasi, proliferasi, dan angiogenesis yang didinduksi oleh asap rokok. EGCG yang diberikan sebagai pre treatment pada sel epitel memberikan efek penghambatan terhadap proses inflamasi dan proliferasi.

\section{KESIMPULAN}

Pemberian teh hijau dengan dosis P2 $0,020 \mathrm{gr} / \mathrm{bb} / \mathrm{hari}$ dalam $1 \mathrm{ml}$ aquadest selama 14 hari berturut-turut dapat mencegah kerusakan struktur histologist alveolus paru mencit yang disebabkan oleh paparan asap rokok.Pemberian paparan asap rokok selama 14 hari menyebabkan kerusakan struktur histologis paru mencit yang ditandai dengan adanya destruksi septum alveolar, infiltrasi sel radang dan edema.

\section{DAFTAR PUSTAKA}

Anindita, R., Soeprobowati, T.R., dan Suprapti, N.H., 2012. Potensi The Hijau (Camellia sinensis L.) dalam Perbaikan Fungsi Hepar Pada Mencit yang Diinduksi Mono Sodium Glutamat (MSG). Buletin Anatomi Fisiologi. Semarang: Universitas Diponegoro. 
Aulia, L. E. 2010. Stop Merokok. Yogyakarta : Garailmu.

Bakhtiar, A., Amran, W.S., 2016. Faal Paru Statis. Departemen Pulmonologi dan Ilmu Kedoktersn Respirasi. Fakultas Kedokteran Universitas Airlangga. J Respirasi Vo. 2 No. 3.

Batubara, I.V.D., Wantouw, B., dan Tendean, L., 2013.Pengaruh Paparan Asap Rokok Kretek Terhadap Kualitas Spermatozoa Mencit Jantan. J. e-Biomedik. 1(1): 331.

Chaturvedula, V.S.P., dan Prakash, I., 2011. The aroma, taste, color and bioactive constituents of tea.J Medicinal Plants Research.Vol. 5(11).

Eroschenko, V.P., 2012. Atlas Histologi diFiore Dengan Korelasi Fungsional, Edisi Ke-11. Ahli Bahasa, Brahm U Pendid. ; Editor Edisi Bahasa Indonesia, Didiek Dharmawan, Nella Yesdelita. Jakarta : EGC

Fajar, R.I., Wrasiati, L.P.,dan Suhendra, L., 2018. Kandungan Senyawa Flavonoid Dan Aktivitas Antioksidan Ekstrak Teh Hijau Pada Perlakuan Suhu Awal Dan Lama Penyeduhan. Jurnal Rekayasa dan Manajemen Agroindustri Vol. 6, No.3, 196-202.

Habiburrohman, D., dan Sukohar, A., 2018.Aktivitas Antioksidan dan Antimikrobial pada Polifenol Teh Hijau. J Agromedicine Unila 5(2): 587.

Hidayat, N.R., Ramadhan, M.A., dan Rusli, R., 2016. Analisis Kadar Nikotin Rokok Herbal Indonesia.Buku Prosiding Seminar Nasional Kefarmasian Ke III. Fakultas Farmasi Universitas Mulawarman. Samarinda, $20-21$ April 2016.
Hussain, A., Dulay, P., Rivera, M.N., Aramouni, C., dan Saxena, V., 2019. Neoplastic Pathogenesis Asociated with Cigarette Carcinogens.

Joseph, V., 2016. Efek Akut Merokok Kretek Terhadap Fungsi Ventrikel Kanan.J Biomedik. Vol. 8 No. 2(23-25).

Kartika, A.A., Siregar, H.C.H., dan Fuah, A.M., 2013. Strategi Pengembangan Usaha Ternak Tikus (Rattus norvegicus) Dan Mencit (Mus musculus) Di Fakultas Peternakan IPB.J Ilmu Produksi dan Tekhnologi Hasil Peternakan.Vol. 01 No. 3.

Putra, A.S., 2019. Pengaruh Pemberian Ekstrak Teh Hijau (Camellia sinensis) Terhadap Gambaran Histopatologi Silia Pada Trakea Tikus Putih Jantan Galur Sporague Dawley Yang Dipapar Uap Rokok Elektronik. [Skripsi]. Fakultas Kedokteran. Universitas Lampung Bandar Lampung.

Putra, A.S., 2015. Perbandingan Efek Asap Rokok Konvensional Dan Rokok Herbal Terhadap Kerusakan Histologis Paru Mencit (Mus musculus). [Skripsi]. Fakultas Kedokteran. Universitas Muhammadiyah Surakarta.

Putra, Y., 2014. Pengaruh Rokok Teradap Jumlah Sel Spermatozoa Mencit Jantan (Mus musculus, Strain Jepang). J Sainstek1 : $30-42$.

Putra, A.I., 2019. Pengaruh Paparan Asap Rokok Elektrik Dan Paparan Asap Rokok Konvensional Terhadap Gambaran Histopatologi Paru Mencit Jantan. [Skripsi]. Fakultas Kedokteran. Universitas Lampung.

Rabb, H., Griffin, M.D., McKay, D.B., Swaminathan, S., Pickkers, P., Rosner, M.H., Kellum, J.A., and Ronco, C., 2016. Inflammation in AKI: Current Understanding, Key Question, and Knowledge Gaps. J Am Soc Nephrol 27: 371-379. 
Rani Dwi Nurjanah, "Pengertian Merokok dan Akibatnya",http://ranidwi68.wordpr ess.com/2013/01/09/pengertianmerokok-dan akibatnya/, diakses 16 Januari 2020.

Ravindranath, N.H., and Ravindranath, .H., 2011. Green tea catechins suppress NF-KB- mediated inflammatory responses: relevance to nutritional management of inflammation. British Journal of Nutrition 105 : 1715-1717.

Rohmani, A., Yazid, N., dan Rahmawati, A.A., 2018.Rokok Elektrik dan Rokok Konvensional Alveolus Paru.Fakultas Kedokteran Universitas Muhammadiyah Semarang.

Sofianto, Hulfron. 2010. Mengenal Bahaya Rokok Bagi Kesehatan. Bogor: Yudhistira. 56 halaman.

Solfaine, 2019. Patogenesis Dasar Penyakit Hewan. Surabaya. Hal.187 $-188$.

Tortora, Gerard, J., and Bryan Derrickson, 2012.Principle of Anatomy and Physiology.USA : John Wiley and Sons Inc

Towaha, J., dan Balittri., 2013. Kandungan Senyawa Kimia Pada Daun Teh (Camellia sinensis). Warta Penelitian dan Pengembangan Tanaman Industri 19(3): 13.

Tirtosastro, S., dan Murdiyati, A.S., 2010. Kandungan Kimia Tembakau dan Rokok. Balai Penelitian Tanaman Tembakau dan Serat, Malang.

Yildirim, A.O., Muyal, V., John, G.R., Muller, B., Seifart, C., Kasper, M., and Fehrenbach, H., 2010. Palifermin Induces Alveolar Maintenance Programs in
Emphysematous Mice. J Respir Crit Care Med. 181: 705-706.

Yusni., Husni, T., dan Achamd, T.H., 2015. Aktivitas Polifenol Teh Hijau (Camellia sinensis (L)O. Kuntze) Sebagai Imunomodulator melalui Respons Supresi Imunoglobulin E (IgE) pada Rinitis Alergika. 47(3): 161.

Yuslianti, E.R., 2018. Pengantar Radikal Dan Antioksidan. Yogyakarta. 4 - 5.

Zhao, C.N., Tang, G.Y., Cao, S.Y., Xu, X.Y., Gan, R.Y., Liu, Q., Mao, Q.Q., Shang, A., and Li, H.B., 2019. Phenolic Profiles and Antioxidant Activities of 30 Tea Infusions from Green, Black, Oolong, White, Yellow and Dark Teas.Sun Yat-Sen University, Guangzhou,China. 